\title{
DISCIPLINOVANOST UČENIKA U GRČKIM SREDNJIM ŠKOLAMA U ODNOSU NA POL, ZAINTERESOVANOST ZA NASTAVU FIZIČKOG VASPITANJA I SPORTSKE AKTIVNOSTI
}

\author{
Panteleimon Bakirtzoglou' ${ }^{1}$ Panagiotis Ioannou ${ }^{2}$
}

${ }^{1}$ Organizacija za stručno obrazovanje i obuku u Grčkoj, Atina, Grčka

${ }^{2}$ Fakultet fizičkog vaspitanja i sportskih nauka, Univerzitet Solun, Grčka

ORGINALNI NAUČNI ČLANAK

doi: 10.5550/sgia.110702.se.101B

COBISS.BH-ID: 2427416 UDK: 37.016:796(38)

\section{SAŽETAK}

Cilj ove studije je bio da se uporede razlike između pojedinih grupa učenika (u zavisnosti od pola, vrste škole koja se pohađa, i zainteresovanosti za fizičko vaspitanje i sportske aktivnost van same nastave) koje se ispoljavaju kroz njihovo disciplinovano ili nedisciplinovano ponašanje na časovima fizičkog vaspitanja. Uzorak ispitivanja se sastojao od 565 srednjoškolskih učenika, uzrasta od 15 do 16 godina starosti, iz šire oblasti Atine u Grčkoj. Učesnici u ispitivanju su kompletirali sljiedeće skale za procjenu stanja: skala razloga za disciplinovanost (RDS) i skala strategija za održavanje discipline na času (SSDS). Rezultati su pokazali da je disciplinovanost prisutnija među učenicima ženskog pola koje su istovremeno i percipirale više intrinzičkih razloga za održavanje discipline kod svojih profesora fizičkog nego što su to radili učenici muškog pola. Dječaci su skloniji nedisciplinovanom ponašanju i percipiraju više razloga za ravnodušnost ili intorjekciju kod svojih profesora. Sa druge strane, svi učenici kojima se dopada nastava fizičkog vaspitanja i koji se bave sportom imaju disciplinovanije ponašanje i percipiraju više intrinzičkih razloga za održavanje discipline kod svojih profesora.

Ključne riječi: disciplina, učenici nastave fizičkog vaspitanja, pol, sportska aktivnost.

\section{UVOD}

Jedan od aspekata koji se najviše tiče stručnjaka i istraživača u oblasti fizičkog vaspitanja je razumijevanje kognitivnih mehanizama koji uslovljavaju disciplinovano odnosno nedisciplinovano ponašanje na nastavi (Lewis, 2001; Siedentop, 1991).

Disciplina učenika na nastavi je bojazan koja je prisutna kod mnogih prosvjetnih radnika (Doyle, 1986). Kako bi se stvorilo okruženje za cjelishodan nastavni process, nastavnicima je neophodna i predusretljivost od strane učenika kojima predaju (Rink, 1998). Ukoliko se ne ostvari takav odnos, tj. ako se ponašanje učenika ne kontroliše, može se doći u situaciju da se ne ispune ciljevi nastavnog procesa i da se ugrozi sam osjećaj kompetentnosti prosvjetnog radnika za svoj posao. (Vogler i Bishop, 1990).

Harrison i Blakemore (1992) definišu disciplinu kao prihvatljivo društveno ponašanje u atmosferi koja podstiče učenje. Siedentop (1991) definiše disciplinu kao upravljanje ponašanjem koje je u skladu sa obrazovnim ciljevima u procesu učenja.
Pozitivna iskustva iz nastave fizičkog vaspitanja će poslužiti đacima da usvoje fizičku aktivnost kao dio životnog stila jednom kada postanu odrasle osobe (Goudas, Biddle i Fox, 1994; Sallis i McKenzie, 1991). U tom smislu, od ključne je važnosti da se poznaju motivacioni, kognitivni i afektivni (emocionalni) procesi koji određuju doživljavanje nastave fizičkog vaspitanja od strane đaka kao važna, ugodnaa i prijatna iskustva, ili eventualno kao nešto što donosi neprijatne, dosadne i ponižavajuće podražaje (Atkinson, 1977; Ntoumanis, 2001).

Tri su moguća uzroka zbog kojih se učenici loše vladaju na časovima: roditelji, đaci i nastavnici (Brophy i Rohrkemper, 1981; Emmer, 2001; Ishee, 2004). Bez obzira na koji se nastavne metode odluče, uspjeh u postizanju ovih ciljeva je potpuno zavisan od valjanog funkcionisanja instruktivnih i upravljačkih vještina nastavnog osoblja. (Hammer i saradnici, 2010; Harrison i Blakemore, 1992). Način na koji se razvija i održava nastavno okruženje direktno utiče na ponašanje đaka i uspješnost učenja (Rink, 1998). 
Teorija postizanja određenog cilja u nastavi fizičkog vaspitanja (Ames, 1992; Nicholls, 1989) je bila teorijski model koji je najviše doprinio razumijevanju kognitivnih, ponašajnih i emocionalnih obrazaca kada se govori o postignućima učenika na nastavi fizičkog vaspitanja (Papaioannou, 1998b). Ključni aspekti, poput disciplinovanog ponašanja, prosocijalnog odnosa prema drugima, razvijanja sportskog duha i moralnih vrijednosti u nastavi fizičkog vaspitanja, analizirani su kroz prizmu teorije postizanja određenog cilja (Bortoli, Bertollo, Comani i Robazza, 2011; Duda i Huston, 1995; Duda, Olson i Templin, 1991; Kavussanu i Roberts, 2001; Papaioannou, 1997, 1998b; Spray i Wang, 2001). Istrajnost u vježbanju je recimo povezana sa pomenutom motivacionom strukturom. Na primjer, mladi sportisti pominju zabavu kao glavni razlog zbog kojeg se bave sportom (Carrol i Loumidis, 2001; Gill, Gross i Huddleston, 1983). Ovaj osjećaj zabave je uslovljen doživljavanjem ličnog unaprijeđenja, poboljšanja određenih vještina i uzbuđenja (Boyd, Weinmann i Yin, 2002; Wang, Liu, Chatzisarantis i Lim, 2010; Wankel i Kreisel, 1985; Wankel i Sefton, 1989).

Na uzorku od 254 učenika srednjih škola u Grčkoj, Hassandra, Goudas i Chroni (2003) zapažaju da širok spektar socijalnih faktora $i$ individualnih razlika utiču na intrinzičku motivaciju učenika na nastavi fizičkog vaspitanja. O ovome treba voditi računa kada se sastavljaju planovi za časove fizičkog.

Motivaciona klima je pojam koji se odnosi na društvene i kontekstualne znakove kroz koje socijalni agenti definišu svoje uspjehe odnosno neuspjehe. Što se tiče discipline učenika Papaioannou (1998a) i Spray (2002) ukazuju na to da percepcija okruženja u kojem se zna tačan zadatak koji treba postići jeste povezana sa intrinzičkim $\mathrm{i}$ identifikovanim razlozima koje nastavnici fizičkog vaspitanja podstiču kao uzorno ponašanje na časovima fizičkog vaspitanja. Sa druge strane, percepcija okruženja sa izraženim ego karakteristikama ima više izgleda da podstakne različite načine u kontrolisanju motivacije, i to zbog podupiranja eksternih kriterijuma pri ocjenjivanju. $U$ ovakvom okruženju naglasak se stavlja na trud i predan rad, a učenici, sa druge strane, postižu bolje rezultate od svojih vršnjaka i vode računa o greškama koje prave (Ames, 1992; Papaioannou, 1998b; Spray, 2002).

Skorašnje studije pokazuju povezanost između percepcije motivacionog okruženja i discipline učenika. Na uzorku od 456 učenika u školama u Španiji, Moreno, Cervello i y Martinez Galindo (2007) zapažaju da učenici ženskog pola pokazuju veći stepen discipline i percipiraju više intrinzičkih razloga kod svojih nastavnika kada je u pitanju disciplina, dok učenici muškog pola pokazuju veći stepen nediscipline i zapažaju više razloga za nezainteresovanost odnosno introjekciju kada su u pitanju njihovi nastavnici i način na koji oni održavaju discipline u razredu. Cervello, Jimenez, Del Villar, Ramos i Santos-Rosa (2004) u svom radu pokazuju da je percepcija motivacione klime sa zadacima za ispunjavanje određenog cilja u pozitivnoj vezi sa ispoljavanjem disciplinovanijeg ponašanja, dok je percepcija motivacione klime sa ego-orijentisanim zadacima povezana sa većim stepenom nediscipline na časovima fizičkog vaspitanja. Spray i Wang (2001) zapažaju da učenici koji postižu slabe rezultate u obe vrste okruženja i koji imaju slabo znanje iz oblasti fizičkog vaspitanja imaju takođe i slab stepen samopoimanja. Oni istovremeno procjenjuju svoju disciplinu na časovima fizičkog vaspitanja ispod nivoa u poređenju sa onim učenicima koji pokazuju zavidne rezultate kako na ego-orijentisanim tako i na zadacima sa ispunjavanjem određenog cilja. Đaci sa ovako dobrim rezultatima vjeruju svojim fizičkim sposobnostima i posjeduju osjećaj izvjesnog stepena autonomnosti u svom ponašanju kao i visok stepen disciplinovanog ponašanja.

S druge strane, Heaven (1996) smatra da je stvaranje slike o sebi, odnosno proces samopoimanja, jedan od izazova sa kojima se adolescent trebaju suočiti. Različite studije pokazuju da pojedinci sa većim stepenom sopstvene motivacije (intrinzičke) ispoljavaju veći stepen discipline, dok osobe sa niskim stepenom samomotivacije pokazuju sklonost nedisciplini i ponašanju koje remeti nastavu (Papaioannou, 1998a; Papaioannou i Kouli, 1999).

Cilj ove studije je upoređivanje razlika zasnovanih na disciplinovanom odnosno nedisciplinovanom ponašanju učenika na časovima fizičkog vaspitanja u grčkim srednjim školama, i to razlika koje proizilaze iz vrste škole koju pohađaju, zainteresovanosti za nastavu fizičkog vaspitanja i sportske aktivnosti van škole, kao i pola kome pripadaju.

\section{METODE}

\section{Uzorak}

Uzorak ove studije se sastoji od 563 učenika srednjih škola uzrasta od 15 do 16 godina $(M \pm S D: 15,7$ $\pm 0,52)$. Uzorak se satojao od podjednakog broja učenika muškog i ženskog pola sa šireg područja Atine podijeljenih u dvije polne skupine. Procentualno govoreći, 46,4\% učenika su bili iz državnih škola a 53,6\% su pohađali private škole. Od tog broja, 312 učesnika u istraživanju se bavilo sportskom aktivno- 
šću mimo nastave fizičkog vaspitanja dok ih je 144 reklo da ne praktikuju fizičke aktivnosti van nastave. Uz to, 378 ih je reklo da vole fizičko vaspitanje a 78 da ga ne vole. Svi učesnici su se dobrovoljno javili da učestvuju u istraživanju.

\section{Procedure}

Direktori su škola u kojima se istraživanje sprovelo dali saglasnost za sprovođenje istog. Učenici su bili upoznati sa svrhom istraživanja i svojim pravima, te je od njih bilo zatraženo da potpišu izjavu o sagla- snosti. Instrumenti za mjerenje različitih varijabli dati su učenicima dok su bili u učionicama, i to onda kad nije bilo profesora fizičkog vaspitanja. Oni su bili dati svakom učeniku istim redoslijedom. Svakom daku je trebalo 15 do 20 minuta da ispuni upitnike a njihovi odgovori su držani u anonimnosti. Takođe, svakom đaku je rečeno da zatraži pomoć u slučaju da im nije jasno šta se od njih traži, odnosno kako su formulisana pitanja. U cijelom toku popunjavanja obrazaca nije primijećeno da učenici nisu razumjeli suštinu pitanja odnosno način na koji ih treba popuniti.

\section{TABELA 1}

Aritmeticke sredina i standardna devijacija za socio-demografske varijable pola nicenika i vrste škole koju pohadaju

\begin{tabular}{lcccc}
\hline \multicolumn{1}{c}{ Pol } & \multicolumn{2}{c}{ Dječaci } & \multicolumn{2}{c}{ Djevojčice } \\
\hline Skala razloga & $M$ & $S D$ & $M$ & $S D$ \\
\hline Identifikovani razlozi & 74,20 & 15,32 & 81,44 & 12,20 \\
\hline Introjektovani razlozi & 58,30 & 22,84 & 67,30 & 21,93 \\
\hline Intrinsički razlozi & 73,46 & 17,28 & 78,41 & 16,80 \\
\hline Amotivacija & 42,88 & 21,63 & 39,41 & 23,91 \\
\hline Pažnja prema drugima & 61,97 & 19,94 & 69,46 & 18,41 \\
\hline Skala strategija & & & & \\
\hline Pažnja i odgovornost & 69,34 & 15,93 & 72,17 & 16,22 \\
\hline Intrinzička & 68,69 & 17,30 & 73,99 & 18,05 \\
\hline Introjektovana i eksterna & 45,81 & 21,30 & 35,41 & 23,98 \\
\hline Ravnodušnost & 39,40 & 24,93 & 31,28 & 24,40 \\
\hline \multicolumn{1}{c}{ Vrsta škole } & Državna & Privatna \\
\hline Skala razloga & $M$ & $S D$ & $M$ & $S D$ \\
\hline Identifikovani razlozi & 78,83 & 13,40 & 77,91 & 15,94 \\
\hline Introjektovani razlozi & 65,21 & 22,80 & 60,34 & 22,90 \\
\hline Intrinsički razlozi & 72,60 & 19,14 & 78,88 & 16,82 \\
\hline Amotivacija & 47,56 & 21,69 & 39,69 & 22,11 \\
\hline Pažnja prema drugima & 67,31 & 19,59 & 64,94 & 19,02 \\
\hline Skala strategija & & & & \\
\hline Pažnja i odgovornost & 67,61 & 17,40 & 71,88 & 15,90 \\
\hline Intrinzička & 66,69 & 20,51 & 75,49 & 15,91 \\
\hline Introjektovana i eksterna & 49,09 & 21,67 & 39,41 & 22,21 \\
\hline Ravnodušnost & 41,55 & 25,55 & 33,32 & 20,19 \\
\hline & & & &
\end{tabular}

\section{Skala razloga za disciplinu na času (RDS)}

Ovaj upitnik mjerio je razloge zbog kojih su se učenici ponašali na izvjestan način na časovima fizičkog vaspitanja (Papaioannou, 1998a). Izvorni obrazac za ovu svrhu koji je sastavio Papaioannou sastojao se od 26 pojedinačnih stavki podijeljenih na 6 faktora: intrinzički razlozi za određeno ponašanje, eksterni razlozi ponašanja, razlozi neponašanja, introjektovani razlozi za određeno ponašanje, razlozi ponašanja koji proističu iz lične odgovornosti i razlozi koji proističu iz pažnje prema drugima. Pokazalo se da postoji pet faktora (eliminisali smo eksterne razloge ponašanja) koje je trebalo posložiti kao stavke, sa određenom modifikacijom u odnosu na prvobitni upitnik, i to na slijedeći način: identifikovani razlozi 
(npr. Važno mi je da obraćam pažnju), intrinzički razlozi (npr. Uživam na časovima fizičkog), introjektovani razlozi (npr. Neću se dobro osjećati ako se loše ponašam), amotivacija (npr. Ne znam zašto se ponašam disciplinovano), i razlozi koji proističu iz pažnje prema drugima (npr. Volim pomagati svojim drugovima u razredu). Pouzdanost podataka koja je dobivena za svaki od ovih faktora je slijedeća: 0,86; 0,76 ; 0,$71 ; 0,58$ i 0,66 , (redoslijedom kojim su navedeni u prethodnoj rečenici). Samo se kod dva faktora pokazala pouzdanost sa alfa vrijednošću ispod 0,70

\section{TABELA 2}

Statistickea sredina $i$ standardne devijacije za socio-demografske varijable zainteresovanosti za nastavu fizičkog vaspitanja i sportske aktivnosti van škole.

\begin{tabular}{lcccc}
\hline \multicolumn{1}{c}{ Zaintersovanos za FV } & \multicolumn{2}{c}{ Nezainterovanost } & \multicolumn{2}{c}{ Zainterovanost } \\
\hline Skala razloga & $M$ & $S D$ & $M$ & $S D$ \\
\hline Identifikovani razlozi & 69,38 & 20,59 & 80,22 & 13,12 \\
\hline Introjektovani razloti & 61,30 & 28,10 & 61,28 & 21,69 \\
\hline Intrinzički razlozi & 54,49 & 21,59 & 75,45 & 16,39 \\
\hline Amotivacija & 44,20 & 22,99 & 41,34 & 22,41 \\
\hline Pažnja prema drugima & 58,37 & 24,60 & 66,69 & 19,53 \\
\hline Skala strategija & \multicolumn{5}{c}{} \\
\hline Pažnja i odgovornost & 55,49 & 21,49 & 71,30 & 15,12 \\
\hline Intrinzička & 52,30 & 25,13 & 72,90 & 16,98 \\
\hline Introjektovana i eksterna & 45,28 & 21,92 & 41,89 & 22,81 \\
\hline Ravnodušnost & 31,99 & 22,95 & 33,69 & 24,44 \\
\hline \multicolumn{1}{c}{ Sportska aktivnost } & Ne bavi se sportom & Bavi se sportom \\
\hline Skala razloga & $M$ & $S D$ & $M$ & $S D$ \\
\hline Identifikovani razlozi & 76,30 & 15,30 & 79,37 & 12,20 \\
\hline Introjektovani razloti & 62,41 & 21,80 & 61,39 & 21,50 \\
\hline Intrinzički razlozi & 70,29 & 17,56 & 75,40 & 19,34 \\
\hline Amotivacija & 40,84 & 21,36 & 40,66 & 21,64 \\
\hline Pažnja prema drugima & 63,69 & 19,50 & 68,68 & 19,56 \\
\hline Skala strategija & \multicolumn{5}{l}{} \\
\hline Pažnja i odgovornost & 66,21 & 15,91 & 72,40 & 15,91 \\
\hline Intrinzička & 65,40 & 17,40 & 75,28 & 17,41 \\
\hline Introjektovana i eksterna & 42,38 & 24,40 & 43,27 & 24,41 \\
\hline Ravnodušnost & 36,55 & 25,41 & 37,80 & 25,81 \\
\hline
\end{tabular}

\section{Strategije za uspostavljanje skale disciplinovanosti (SSDS)}

Prvobitni oblik upitnika je kreirao Papaioannou (1998a) bazirajući ga na teorijskoj osnovi i straživanju koje su sproveli Ryan i Connell (1989) i Vallerand i saradnici (1992) sa ciljem da evaluira percepciju učenika o strategijama koje njihovi profesori fizičkog vaspitanja koriste kako bi održali discipline na časo-
(Nunnally, 1978). Budući da je u pitanju mali broj stavki, i da se alfa koeficijent odnosi na stavke koji su sačinjavali oba faktora (broj stavki je bio 3), registrovana unutrašnja konzistentnost podataka može biti prihvaćena (Nunnally i Bernstein, 1994). Na početku stavki koje su sačinjavale upitnik stajalo je: "Na časovima fizičkog vaspitanja [...]". Odgovori su ocjenjivani po principu Likeritove skale sa rasponom od 0 (u potpunosti se ne slažem) do 100 (u potpunosti se slažem). 
grupisane u 4 faktorske cjeline: naglasak koji profesor stavlja na razloge koji proističu iz brige i odgovornosti za napredovanje (npr. Pomaže nam da budemo odgovorni za naše napredak), naglasak koji profesor stavlja na intrinzičke razloge (npr. Časove fizičkog čini zabavnim), naglasak koji profesor stavlja na introjektovane i eksterne razloge (npr. Ako se loše ponašamo, profesor će učiniti da se zbog toga loše osjećamo), ravnodušnost profesora fizičkog vaspitanja prema disciplini na času (npr. Osjećamo se kao da na času i ne postoji disciplina). Pouzdanost rezultat koji su dobijeni bila je: 0,86; 0,88; 0,76 i 0,70, (redoslijedom kojim su navedeni u prethodnoj rečenici). Na početku stavki koje su sačinjavale upitnik stajalo je: "Profesor fizičkog vaspitanja [...]". Odgovori su ocjenjivani po principu Likeritove skale sa rasponom od 0 (u potpunosti se ne slažem) do 100 (u potpunosti se slažem).

\section{Socio-demografske varijable}

Uz sve prethodno navedeno, prikupljani su i podaci o karakteristikama učenika koji se tiču njihovog ličnog i demografskog okruženja. Analizirane varijable bile su slijedeće: pol učenika (muški ili ženski), vrsta škole (državna ili privatna), zainteresovanost za nastavu fizičkog vaspitanja (zainteresovani ili nezainteresovani) i bavljenje sportskim aktivnosti mimo časova fizičkog vaspitanja (bavi se odnosno ne bavi se nikakvim sportom). Ovdje se pod sportskom aktivnošću podrazumijeva bilo koja fizička aktivnost (aerobik, trčanje, dizanje tegova, plivanje, itd.) ili sportovi (fudbal, košarka) kojim se đaci bave kada nisu na časovima fizičkog vaspitanja.

\section{Statistička analiza}

Kako bi se obradili prikupljeni podaci, u ove svrhe korišten je statistički program SPSS 17.0. Za sve varijable su dobijeni deskriptivne statističke sredine kao i standardne devijacije. Kod nekih varijabli pristup statističkom testiranju subjekata je bio drugačiji. Univarijantna faktorska struktura subjekata je razvijena uz korišćenje ANOVA analize varijance sa jednim faktorom prilikom čega su uspostavljene značajne razlike koje zavise od pola učenika, vrste škole koju pohađaju, zainteresovanosti za časove fizičkog vaspitanja i sportske aktivnosti van nastave (nezavisne varijable), kao i od svakog faktora koji formira oba uptnika (zavisne varijable). MANOVA analiza varijance je korištena da se identifikuju značajne razlike na način da se uspostavi interakcija izmedu svake varijable pojedinačno i svih faktora koji sačinjavaju oba upitnika.

TABELA 3

Univarijantna $i$ multivarijantna analiza $R D S$ i SSDS-a

\begin{tabular}{|c|c|c|c|c|c|}
\hline Varijable & Pol & Vrsta škole & $\begin{array}{c}\text { Zaintersova- } \\
\text { nost za FV }\end{array}$ & $\begin{array}{l}\text { Sportske } \\
\text { aktivnosti }\end{array}$ & $\begin{array}{c}\text { Škola + } \\
\text { Zainteresov. }\end{array}$ \\
\hline \multicolumn{6}{|l|}{ Skala razloga } \\
\hline Identifikovani razlozi & $26,80 * *$ & 1,15 & $11,44^{* *}$ & 0,01 & $5,68^{*}$ \\
\hline Introjektovani razlozi & $15,91 * *$ & 3,56 & 0,09 & 0,04 & 3,91 \\
\hline Intrinzički razlozi & $8,33 * *$ & $8,14^{*}$ & $42,28^{* *}$ & $6,12 * *$ & 0,77 \\
\hline Amotivacija & $7,71 * *$ & $33,69 * *$ & 0,41 & 0,00 & $4,12^{*}$ \\
\hline Pažnja prema drugima & $12,28^{* *}$ & 1,33 & 2,98 & 0,25 & $7,68^{*}$ \\
\hline \multicolumn{6}{|l|}{ Skala strategija } \\
\hline Pažnja i odgovornost & 2,91 & $11,24 *$ & $22,98^{* *}$ & $7,17 * *$ & 0,00 \\
\hline Intrinzička & $5,88 * *$ & $23,87 * *$ & $37,69 * *$ & $8,68 * *$ & 1,92 \\
\hline Introjektovana i eksterna & $16,33^{* *}$ & $25,97 * *$ & 1,58 & 0,01 & 0,82 \\
\hline Ravnodušnost & $15,41 * *$ & $44,68^{* *}$ & 0,19 & 0,21 & 0,33 \\
\hline \multicolumn{6}{|l|}{ Multivarijantna analiza } \\
\hline$\Lambda$ & 0,94 & 0,91 & 0,93 & 0,90 & 0,93 \\
\hline$F$ & $3,38 * *$ & $2,14^{*}$ & $4,12 * *$ & $2,18^{*}$ & $2,64 *$ \\
\hline
\end{tabular}

Legenda: $*-p<0,05 ; * *-p<0,01 ; \boldsymbol{\Lambda}-$ Wilksov multivarijantni test kriterijum; $\boldsymbol{F}-\mathrm{F}$ distribucija. 


\section{REZULTATI}

Tabela 1 predstavlja deskriptivnu statističku vrijednost (aritmetičke sredine i standardne devijacije) za varijable pola učenika i vrste škole koju pohađaju. Kao što se može i vidjeti, djevojčice su postigle bolje rezultate u većini faktora iz oba upitnika (RDS i SDDS).

Tabela 2 predstavlja deskriptivnu statističku vrijednost (aritmetičke sredine i standardne devijacije) za varijable zainteresovanosti za nastavu fizičkog obrazovanja i sportske aktivnosti van nastave. Kao što se može vidjeti, učenici koji vole časove fizičkog i koji se bave sportom i poslije škole ispoljavaju više discipline na časovima i percipiraju više intrinzičkih razloga koje koriste njihovi profesori kako bi uspostavili i održali disciplinu na času.

Tabela 3 prikazuje rezultate univarijantnih razlika. Kada se posmatra odnos između varijable pola učenika i svih uspostavljenih faktora, primjećuje se značajna razlika kod svih faktora u skali razloza za discipline (DS): identifikovani razlozi $(F=26,80, p<0,01)$, introjektovani razlozi $(F=15,91, p<0,01)$, intrinzički razlozi $(F=8,33, p<0,05)$, nemotivisanost $(F=$ $7,71, p<0,05)$ i pažnja prema drugima $(F=12,28, p$ $<0,01)$, a u tri od četiri faktora u skali SSDSS: naglasak na intrinzičke razloge $(F=5,88, p<0,05)$, naglasak na introjektovane i eksterne razloge $(F=16,33$, $p<0,01)$ i ravnodušnost profesora fizičkog prema disciplini na času $(F=15,41, p<0,01)$.

Što se tiče varijable vrste škole koja se pohađa, pronalazimo značajne razlike u faktorima koji pripadaju RDS-u: intrinzički razlozi $(F=8,14, p<0,05)$ i nemotivisanost $(F=33,69, p<0,01)$, kao i kod faktora koji se odnose na strategije koje koriste profesori kako bi održali disciplinu na času fizičkog vaspitanja kao što su: naglasak na razloge koji proizilaze iz pažnje i odgovornosti $(F=11,24, p<0,05)$, naglasak na intrinzičke razloge $(F=23,87, p<0,01)$, naglasak na introjektovane i eksterne razloge $(F=25,97, p<0,01)$ i ravnodušnost profesora fizičkog $(F=44,68, p<$ 0,01).

Kada govorimo o varijabli koja se odnosi na zainteresovanost za nastavu fizičkog vaspitanja, uočili smo značajne razlike za identifikovane razloge $(F=$ $11,44, p<0,05) \mathrm{i}$ intrinzičke razloge $(F=42,28, p<$ $0,01)$ kod faktora u RDS-u, kao i za naglasak na pažnju i odgovornost dat od strane profesora $(F=22,98$, $p$ $<0,01)$ i naglasak profesora na intrinzičke razloge ( $F$ $=37,69, p<0,01)$ u SSDS-u.

Kod varijable bavljenja sportom van nastave fizičkog vaspitanja, signifikantne razlike su primijećene samo kod faktora intrinzičkih razloga za ponašanje $(F=6,12, p<0,05)$ u RDS-u, kod profesorovog naglaska na razloge koji su vezani za pažnju i odgovornost prema drugima $(F=7,17, p<0,05)$ i profesorovog naglaska na intrinzičke razloge kod održavanja nastave na časovima fizičkog vaspitanja $(F=8,68$, $p<0,05)$.

Nakon sprovođenja MANOVA analize varijance (Tabela 3), signifikantne razlike su nađene u odnosu koji su uspostavile stavke vrste škole koje učenici pohađaju (državna ili privatna) i zainteresovanosti za nastavu fizičkog vaspitanja $(\Lambda=0,94, F(9,335)=$ $2,64, p<0,05)$. Posebno su uočljive razlike kod faktora koji pripadaju skali razloga za ponašanje: identifikovani razlozi $(F=5,68, p<0,05)$, amotivisanost $(F=4,12, p<0,05)$ i pažnja prema drugima $(F=7,68$, $p<0,05)$. Kao posljedica takvog stanja, rezultati pokazuju da đaci iz državnih škola koji vole fizičko vaspitanje pokazuju više razloga za odgovornost, amotivisanost, zainteresovanost i pažnju prema svojim drugovima iz razreda nego učenici koje ne vole fizičko vaspitanje čak i kad se uporede sa đacima iz privatnih škola, bez obzira da li oni vole ili ne vole časove fizičkog vaspitanja.

\section{DISKUSIJA}

U ovoj studiji smo imali namjeru uporediti razlike (u odnosu na pol učenika, vrstu škole, zainteresovanost za nastavu fizičkog vaspitanja i sportske aktivnosti van nastave) a koje su zasnovane na disciplinovanom odnosno nedisciplinovanom ponašanju đaka na nastavi fizičkog vaspitanja u grčkim srednjim školama.

Kada se uzme u razmatranje odnos između varijable pola učenika sa svim uspostavljenim faktorima, dobijeni rezultati sugerišu da učenici ženskog pola pokazuju veći stepen razloga koji dolaze iz samomotivisanosti, u odnosu na đake muškog pola, kada je u pitanju disciplina koju ispoljavaju na času, te percipiraju svoje profesore fizičkog kao intrinzički motivisane da održe disciplinu na času. Ovi podaci su se tako pokazali na istom fonu kao i podaci prikupljeni od strane Moreno i saradnici (2007).

Ovakvi rezultati se mogu opravdati činjenicom da pripadnice ženskog pola nemaju potrebu da se takmiče i budu uspješne na časovima fizičkog vaspitanja nego su više zainteresovane za kooperativne aktivnosti, te se iz tog razloga njihovo ponašanje čini disciplinovanijim. Spomenimo i to da su ovi podaci u skladu sa onima koji proističu iz istraživanja koje su sproveli Duda i Whitehead (1998), Escartí, Roberts, Cervelló i Guzmán (1999) i White, Kavassanu i Guest (1998). Kako navode pomenuti autori, žene su više orijentisane ka rješavanju određenih zadataka i intrinzički su motivisanije, dok muškarci, sa druge strane, 
ispoljavaju veći stepen ego-orijentisanosti, ekstrinzičkoj motivaciji ili amotivaciji.

Kada je u pitanju vrsta škole koja se pohađa, primjećujemo da učenici iz privatnih škola imaju veću intrinzičku motivisanost u ponašanju na časovima u odnosu na učenike iz državnih škola koji su potpuno amotivisani da se dobro ponašaju. Na sličan način, učenici iz privatnih škola percipiraju svoje profesore kao intrinzički motivisane da održe discipline na časovima fizičkog, brinu o ponašanju đaka i osjećaju se odgovornima za to. Sa druge strane, učenici iz državnih škola su potpuno ravnodušni prema discipline na času, i ako i postoji briga za takvim nečim ona je uglavnom motivisana razlozima zbog kojih žele izbjeći osjećaj krivice odnosno bilo koju vrstu represalija od strane eksternog faktora. Ovakvi zaključci su u skladu sa onima nađenim od strane Moreno i saradnici (2007).

Govoreći o varijablama koje se odnose zainteresovanosti đaka prema fizičkom vaspitanju i bavljenju sportom van škole, pronalazimo značajne razlike kod grupe đaka koja je rekla da voli nastavu fizičkog vaspitanja i da se bavi sportom u slobodno vrijeme, i to sa više samosvjesnijih razloga za disciplinu na času. I ovo je u suglasnosti sa prethodnom studijom (Moreno i saradnici, 2007). To se objašnjava činjenicom da intrinzički motivisani pojedinci učestvuju u pojedinim aktivnostima za svoje vlastito dobro ali i zbog osjećaja zadovoljstva i satisfakcije koju dobijaju samim učestvovanjem (Deci i Ryan, 1985; Dorobantu, i Biddle, 1997; Ntoumanis, 2001; Standage i Treasure, 2002; Wang, Chatzisarantis, Spray i Biddle, 2002; Wang, Liu, Chatzisarantis i Lim, 2010). Autori Hassandra, i saradnici (2003) i Ryan i Deci (2000), kažu da intrinzički motivisane pojedince karakteriše psihološko blagostanje koje dovodi do osjećanja uživanja i satisfakcije onim čime se bavi, a kao posljedicu toga primjećeno je bavljenje sportom mimo nastave fizičkog vaspitanja i ispoljavanje više disciplinovanijeg ponašanja.

Na kraju, kada se govori o interakciji izmedu varijabli vrste škole koja se pohađa i zainteresovanosti za nastavu fizičkog vaspitanja, naši zaključci upućuju na to da učenici iz državnih škola, koji vole nastavu fizičkog vaspitanja, ispoljavaju bolje ponašanje od učenika iz državnih škola koji ne vole časove fizičkog, čak i kad se uporede sa svim učenicima iz privatnih škola. Na jedan kontradiktoran način, učenici pomenutog profila pokazuju u isto vrijeme i više razloga za amotivisanost i nedisciplinovano ponašanje na času fizičkog vaspitanja. I ovi zaključci su u skaldu sa radom Moreno i saradnici (2007).
Istraživanja su pokazala da učenici, kako napreduju kroz različite stepene obrazovanja i sve više percipiraju akademske zahtjeve koje obrazovanje pred njih postavlja, pokazuju stepen opadanja kada je u pitanju učestvovanje u fizičkim aktivnostima (Parish i Treasure, 2003; Trudeau i Shephard, 2005), kao i pad u stepenu percipirane kompetencije (Weiss i Amorose, 2005). Kada se uzme u obzir stepen fizičke samopercepcije i motivacije koja se pojavljuje u prvim godinama adolescencije, važno je razumjeti koji su to motivacioni procesi koji potiču učenike i kako oni djeluju na njihovu fizičku samopercepciju.

Samopoštovanje se podiže fizičkim vježbanjem i tako koristi ljudima kako na psihološkom tako i na fizičkom planu (Boyd i Hrycaiko, 1997). Iz tog razloga učenici koji su fizički aktivni imaju pozitivniju percepciju njihovog samopoimanja, samopoštovanja u svim dimenzijama koji ga sačinjavaju: percepcija tjelesne slike, percepcija sportske kompetencije, fizička kondicija, percepcija opšte fizičke kompetencije i fizičke snage (Bortoli, Bertollo, Comani i Robazza, 2011). Prema Ntoumanisu (2001), pozitivni socijalni faktori poput promovisanja kooperativnog učenja, stavljanja naglaska na individualno unaprijedivanje i promjene u postavljanju zadataka koji se trebaju ispuniti mogu doprinijeti pozitivnim motivacionim rezultatima u fizičkom vaspitanju.

Umjesto zaključka željeli bismo istaći važnost koju ova studija i njoj slične pridaju razumijevanju uzroka koji su u pozadini disciplinovanom odnosno nedisciplinovanom ponašanju na časovima fizičkog vaspitanja. Unutrašnji razlozi za disciplinovano odnosno nedisciplinovano ponašanje na času dovode do boljeg razumijevanja razloga koji doprinose ponašanju koje remete normalan tok časa.

Nadamo se da ovakvi zaključci mogu imati implikacije na samu praksu držanja nastave fizičkog vaspitanja. Časovi bi trebalo da budu struktuirani na način da omogućavaju đacima da zadovolje svoju potrebu za samoposebnošću, kompetencijom u fizičkom vaspitanju i socijalnom povezanošću. Iz tog razloga, đacima se treba dati mogućnost da biraju da li će učestvovati u određenoj aktivnosti kao bi tako doživjeli osjećaj postignuća i imali dovoljno prilika za interakciju sa drugovima iz razred za vrijme časova fizičkog vaspitanja.

\section{LITERATURA}

Ames, C. (1992). Classrooms, goals, structures, and student motivation. Journal of Educational Psychology, 84, 261-271. doi: 10.1037/0022-

0663.84.3.261. 
Atkinson, J. W. (1977). Motivation for achievement. In T. Blass (Ed.), Personality variables in social behavior (pp. 57-68). Hisdale, NJ: Erlbaum.

Bortoli, L., Bertollo, M., Comani, S., \& Robazza, S. (2011). Competence, achievement goals, motivational climate, and pleasant psychobiosocial states in youth sport. Journal of Sports Sciences, 29(2): 171-180. doi: 10.1080 /02640414.2010.530675.

Boyd, K. R., \& Hrycaiko, D. W. (1997). The effect of physical activity intervention package on the self-esteem of pre-adolescent and adolescent females. Adolescence, 32(127): 693-708.

Boyd, M. P., Weinmann, C., \& Yin, Z. (2002). The relationship of physical self perceptions and goal orientations to intrinsic motivation for exercise. Journal of Sport Behavior, 25, 1-18.

Brophy, J. E. \& Rohrkemper, M. M. (1981). The influence of problem ownership on teachers' perceptions of and strategies for coping with problem students. Journal of Educational Psychology, 73, 295-311. doi: 10.1037/00220663.73.3.295.

Carrol, B., \& Loumidis, J. (2001). Children's perceived competence and enjoyment in physical education and physical activity outside school. European Physical Education Review, 7(1): 24-43. doi: 10.1177/1356336X010071005.

Cervello, E. M., Jimenez, R., Del Villar, F., Ramos, L., \& Santos-Rosa F. J. (2004). Goal orientations, motivational climate, equality, and discipline of Spanish physical education students. Perceptual and Motor Skills, 99, 271-283. doi: 10.2466/PMS.99.4.271283; doi: 10.2466/PMS.99.5.271-283; doi: 10.2466/ pms.99.1.271-283.

Deci, E.L., \& Ryan, R.M. (1985). Intrinsic motivation and self-determination in human behavior. New York: Plenum Press.

Dorobantu, M., \& Biddle, S. (1997). The influence of situational and individual goals on intrinsic motivation of Romanian adolescents towards physical education. European Yearbook of Sport Psychology, 1, 148-165.

Doyle, W. (1986). Classroom organization and management. In M. C. Wittrock (Ed.), Handbook on research of teaching (3rd ed.; pp. 392-431). New York: Macmillan.

Duda, J. L., \& Huston, L. (1995). The relationship of goal orientation and degree of competitive sport participation to the endorsement of aggressive acts in American football. In R. Vanfraechem-Raway \& V. Vanden Audweele (Eds.), IX European Congress on Sport Psychology
Proceedings (pp. 655-662). Brussels, Belgia: Belgian Federation of Sport Psychology.

Duda, J. L., \& Whitehead, J. (1998). Measurement of goal perspectives in the physical domain. In J. L. Duda (Ed.), Advances in Sport and Exercise Psychology Measurement. Morgantown, WV: Fitness Information Technology.

Duda, J. L., Olson, L. K., \& Templin, T. J. (1991). The relationship of task and ego orientation to sportsmanship attitudes and the perceived legitimacy of injurious acts. Research Quarterly for Exercise and Sport, 62, 79-87.

Emmer, T. E. (2001). Classroom management: A critical part of educational psychology, with implications for teacher education. Educational Psychologist, 36, 103-104. doi: 10.1207/ S15326985EP3602_5.

Escarti, A., Roberts, G. C., Cervello, E., \& Guzman, J. (1999). Adolescent Goal Orientations and the Perception of Criteria of Success Used by Significant Others. International Journal of Sport Psychology, 30, 309-324.

Gill, D. L., Gross, J. B., \& Huddleston, S. (1983). Participation motivation in youth sports. International Journal of Sport Psychology, 14, 1-14.

Goudas, M., Biddle, S., \& Fox, F. (1994). Perceived locus of causality, goal orientations, and perceived competence in school physical education classes. British Journal of Educational Psychology, 64, 453-463. doi: 10.1111 /j.20448279.1994.tb01116.x.

Hammer, D., Piascik, P., Medina, M., Pittenger, A., Rose, R., Creekmore, ... Scott, S. (2010). Recognition of teaching excellence. American Journal of Pharmaceutical Education, 74(9), 164. doi: 10.5688/ aj7409164.

Harrison, M. J., \& Blakemore, L. C. (1992). Instructional strategies for secondary school physical education. Iowa: Wm. C. Brown Publisher.

Hassandra, M., Goudas, M., \& Chroni, S. (2003). Examining factors associated with intrinsic motivation in physical education: a qualitative approach. Psychology of Sport and Exercise, 4, 211-223. doi: 10.1016/S1469-0292(02)00006-7.

Heaven, P. C. L. (1996). Adolescent health: The role of individual differences. London: Routledge. doi: 10.4324/9780203137161

Ishee, J. H. (2004). Perceptions of misbehavior in middle school Physical Education. Journal of Physical Education, Recreation and Dance, 75, 9.

Kavussanu, M., \& Roberts, G. C. (2001). Moral functioning in sport: an achievement goal per- 
spective. Journal of Sport and Exercise Psychology, 23, 37-54.

Lewis, R. (2001) Classroom discipline and student responsibility: the students' view. Teaching and Teacher Education, 17, 307-319. doi: 10.1016/ S0742-051X(00)00059-7.

Moreno, J. A., Cervello, E., \& Martinez Galindo, C. (2007). Perception of discipline according to gender, type of school, sport activity and interest in physical education in Spanish students. International Journal of Applied Sports Sciences, 19(2), 35-49.

Nicholls, J. G. (1989). The competitive ethos and democratic education. Cambridge, MA: Harvard Univer. Press.

Ntoumanis, N. (2001). A self-determination approach to the understanding of motivation in physical education. British Journal of Educational Psychology, 71, 225-242. doi: 10.1348/ 000709901158497.

Nunnally, J. C. (1978). Psychometric theory. New York: McGraw-Hill.

Nunnally, J. C., \& Bernstein, I. H. (1994). Psychometric theory (3rd ed.). New York: McGrawHill.

Papaioannou, A. (1997). "I agree with the referee's abuse, that's how I also beat...": Prediction of sport violence and attitudes towards sport violence. European Yearbook of Sport Psychology, 1, 113-129.

Papaioannou, A. (1998a). Goal perspectives, reasons for being disciplined and self-reported discipline in the lesson of physical education. Journal of Teaching in Physical Education, 17, 421441.

Papaioannou, A. (1998b). Students' perceptions of the physical education class environment for boys and girls in Greece and the perceived motivational climate. Research Quarterly for Exercise \& Sport, 69, 267-275.

Papaioannou, A., \& Kouli, O. (1999). The effect of task structure, perceived motivational climate and goal orientations on students' intrinsic motivation and anxiety. Journal of Applied Sport Psychology, 11, 51-71. doi: 10.1080/ 10413209908402950.

Parish, L.E. \& Treasure, D.C. (2003). Physical activity and situational motivation in physical education: Influence of the motivational climate and perceived ability. Research Quarterly for Exercise and Sport, 74, 173-182.
Rink, J. E. (1998). Teaching physical education for learning (3rd. ed.). Boston, MS: WCB McGrawHill.

Ryan, R. M., \& Connell, J. P. (1989). Perceived locus of causality and internalization: Examining reasons for acting in two domains. Journal of Personality and Social Psychology, 57, 749-761. doi: 10.1037/0022-3514.57.5.749.

Ryan, R. M., \& Deci, E. L. (2000). Selfdetermination theory and the facilitation on intrinsic motivation, social development, and well-being. American Psychologist, 55, 68-78. doi: 10.1037/0003-066X.55.1.68.

Sallis, J. F., \& McKenzie, L. (1991). Physical education's role in public health. Research Quarterly for Exercise and Sport, 62(2): 124-137.

Siedentop, D. (1991). Developing teaching skills in physical education (3rd ed.). Mountain View, CA: Mayfield.

Spray, C. M. (2002). Motivational climate and perceived strategies to sustain pupils' discipline in physical education. European Physical Education Review, 8, 5-20. doi: 10.1177/ 1356336X020081001.

Spray, C., \& Wang, C. K. (2001). Goal orientations, self-determination and pupils' discipline in physical education. Journal of Sport Sciences, 19, 903-913. doi: 10.1080/026404101317108417.

Standage, M., \& Treasure, D. (2002). Relationship among achievement goal orientations and multidimensional situational motivation in physical education. British Journal of Education Psychology, 72, 87-103. doi: 10.1348/000709902158784.

Trudeau, F., \& Shephard, R. J. (2005). Contribution of school programmes to physical activity levels and attitudes in children and adults. Sports Medicine, 35, 89-105. doi: 10.2165/00007256200535020-00001.

Vallerand, R. J., Pelletier, L. G., Blais, M. R., Briere, N. M., Senecal, C., \& Vallieres, E. F. (1992). The academic motivation scale: A measure of intrinsic, extrinsic, and amotivation in education. Education and Psychological Measurement, 52, 1003-1017. doi: 10.1177/0013164492052004025.

Vogler, E., \& Bishop, P. (1990). Management of disruptive behavior in physical education. Physical Educator, 47(1), 16-26.

Wang, C. K. J., Chatzisarantis, N., Spray, C., \& Biddle, S. (2002). Achievement goal profile in school physical education: Differences in selfdetermination, sport ability beliefs, and physical activity. British Journal of Educational Psychology, 
72, 433-445. doi: 10.1348/000709902320634401.

Wang, J. C., Liu, W. C., Chatzisarantis, N. L., \& Lim, C. B. (2010). Influence of perceived motivational climate on achievement goals in physical education: a structural equation mixture modeling analysis. Journal of Sports and Exercise Psychology, 32(3), 324-338.

Wankel, L. M., \& Sefton, J. M. (1989). A season long investigation of fun in youth sports. Journal of Sport and Exercise Psychology, 11(4): 355-366.

Wankel, L. M., \& Kreisel, P. S. (1985). Factors underlying enjoyment in youth sports: Sport and age group comparisons. Journal of Sport Psychology, 7, 51-64.

Weiss, M. R., \& Amorose, A. J. (2005). Children's self perceptions in the physical domain: Between-and within-age variability in level, accuracy, and sources of perceived competence. Journal of Sport and Exercise Psychology, 27, 226-244.

White, S. A., Kavassanu, M., \& Guest, S. (1998). Goal orientations and perceptions of the motivational climate created by significant others. European Journal of Physical Education, 3, 212-228. doi: 10.1080/1740898980030209.

Primljeno: 20 jula 2011. godine Izmjene primljene: 28. novembar 2011. godine

Odobreno: 28. novembra, 2011. godine

Korespodenciuja: dr Panteleimon Bakirtzoglou Organisation for Vocational Education and Training Ethikis Antistaseos 41 - OEEK

TK.142 34

Athens-Nea Ionia

Grčka

E-mail:bakirtzoglou@gmail.com

Telefon: 0084722220310 